STUDI ALELOPATI Wedelia trilobata, Ageratum conyzoides, Chromolaena odorata

DAN Mikania micrantha TERHADAP PERTUMBUHAN

DAN HASIL SAWI

\title{
ALLELOPATHY STUDY OF Wedelia trilobata, Ageratum Conyzoides, Chromolaena odorata AND Mikania micrantha ON THE GROWTH AND YIELD OF MUSTARD
}

\author{
Donly Avrin Togatorop, Nanik Setyowati dan Uswatun Nurjanah \\ Fakultas Pertanian, Universitas Bengkulu \\ Jl. WR Supratman, Bengkulu 38371 \\ e-mail : nanik_srg@yahoo.com
}

\section{ABSTRACT}

Various results of researches report that daisy Creeping Daisy (Wedelia trilobata), Goat weed (Ageratum conyzoides), Siam weed (Chromolaena odorata) and Bittervine (Mikania micrantha) have alellopathic potency to innhibit germination, growth and plant yield.. There were few researches on allelopathic potential of Creeping Daisy, Goat weed, Siam weed and Bittervine on mustard. Therefore, an experiment to evaluate the the allelopathic effects of those weeds on growth and yield of mustard at different concentrations is necessary to be conducted. The purpose of the research was to determine the allelopathic effects of Creeping Daisy, Goat weed, Siam weed and Bittervine on the germination of mustard. The Experiment was conducted from November 2008 until January 2009 at Agronomy Laboratory, University of Bengkulu using Randomized Complete Design (RCD). The experiment consisted of four weed species namely Creeping Daisy, Goat weed, Siam weed and Bittervine and five allelopathic concentrations 10, 20, 30, 40 and $50 \mathrm{~g} / \mathrm{L}$. The results showed that Siam weed suppressed mustard germination more than other weeds. Allelopathic of Siam weed suppressed shoot length and root length of mustard seedling as much as $42.63 \%$ and $45.15 \%$ respectively. Shoot and root fresh weight and shoot dry weight of mustard seedling were suppressed as much as $28,23 \%$, $56,16 \%$ and $56,7 \%$ respectively The concentration of $50 \mathrm{~g} / \mathrm{L}$ extracts from Goat weed and Siam weed was the most toxic to the germination of mustard. 


\section{PENDAHULUAN}

Gulma dipandang dari sudut agronomis adalah tumbuhan yang tumbuh pada tempat, waktu dan kondisi yang tidak diinginkan. Tumbuhan ini bersaing (berkompetisi) dengan tanaman budidaya untuk memperoleh cahaya matahari, unsur hara dan ruang tumbuh sehingga tanaman utama menjadi tertekan pertumbuhannya (Sastroutomo, 1990).

Seringkali gulma lebih unggul dalam berkompetisi dibandingkan tanaman budidaya. Hal ini disebabkan karena gulma memiliki kecepatan tumbuh yang sangat tinggi, mempunyai kemampuan untuk beradaptasi dengan lingkungan dan dapat berkembangbiak secara vegetatif dan generatif (Sukman dan Yakup, 2002). Beberapa spesies gulma mampu menurunkan kemampuan daya kompetisi dari tumbuhan lain dengan cara melepaskan alelopat. Alelopat merupakan senyawa kimia yang dikeluarkan oleh tumbuhan yang dapat menghambat pertumbuhan tumbuhan di sekitarnya. Senyawa ini dapat menghambat perbanyakan dan pembelahan sel, penyerapan hara dan mineral, laju fotosintesis, sintesis protein serta dapat memperpanjang daya tahan hidup biji-bijian gulma di dalam tanah (Sukman dan Yakup, 2002). Seresah gulma yang memiliki senyawa alelopat dapat mempengaruhi perkecambahan biji tumbuhan yang ada di sekitarnya. Hal ini terjadi karena senyawa alelopat menyebabkan terjadinya penurunan permeabilitas membran biji sehingga imbibisi air dan udara mengalami hambatan (Nie, 2007).

Gulma tahunan dan semusim yang berpotensi alelopati antara : tusuk konde (Wedelia trilobata), babandotan (Ageratum conyzoides), kirinyuh (Chromolaena odorata) dan sembung rambat (Mikania micrantha). Gulma-gulma tersebut diketahui sangat kompetitif dan mampu menghambat pertumbuhan tanaman (Shiming, 2007). Selain itu, Sastroutomo (1990) juga mengemukakan ada 5 jenis gulma tahunan yang memiliki potensi yang sama yaitu teki (Cyperus rotundus), alang-alang (Imperata cylindrica), Shorgum helapense, Cyrcium arvense dan Agropyron repens. 
Berbagai hasil penelitian menunjukkan bahwa keberadaan alelopat pada beberapa jenis gulma dapat berpengaruh negatif terhadap pertumbuhan tanaman. Potensi alelopati pada setiap jenis gulma berbeda-beda dan dapat ditemukan di semua jaringan tumbuhan seperti daun, batang, akar, rizom, bunga, buah dan biji, namun tidak tersebar secara merata sehingga daya hambatnya terhadap tanaman dipengaruhi oleh konsentrasi alelopat.

Besarnya pengaruh alelopat yang diberikan tergantung pada jenis jaringan atau organ tumbuhan karena senyawa alelopat yang dihasilkan tidak tersebar secara merata dalam tubuh tumbuhan. Selain itu perbedaan konsentrasi berpengaruh juga terhadap daya hambat yang dihasilkan. Hasil penelitian Setyowati et al. (1999), menunjukkan bahwa sumber alelopat yang berasal dari daun teki pada konsentrasi $30 \mathrm{~g} / \mathrm{L}$ mampu menekan perkecambahan jagung (Zea mays) dan pada konsentrasi $40 \mathrm{~g} / \mathrm{L}$ untuk kedelai (Glycine max). Sedangkan pada tomat (Lycopersicum esculentum) dan semangka (Citrullus vulgaris) masing-masing pada konsentrasi $20 \mathrm{~g} / \mathrm{L}$ dan $10 \mathrm{~g} / \mathrm{L}$. Pada konsentrasi $50 \mathrm{~g} / \mathrm{L}$ semangka dan tomat tidak lagi mampu untuk berkecambah. Selain itu dilaporkan bahwa ekstrak umbi teki dan rizom alang-alang pada takaran $400 \mathrm{~g}$ per $250 \mathrm{ml}$ air menyebabkan penurunan pertumbuhan dan hasil tanaman mentimun (Cucumis sativus) dibandingkan dengan kontrol (tanpa alelopat) (Fitriana et al., 2005).

Hasil penelitian Nie (2007) menunjukkan ekstrak tusuk konde yang bersumber dari akar, batang, daun dan campuran (akar + batang + daun), mampu menghambat pertumbuhan dan hasil padi (Oryza sativa). Ekstrak tusuk konde mampu menurunkan kandungan klorofil sebesar 39,84\%, dan berat kering tanaman hingga 81,57\%. Selain itu ekstrak tusuk konde dapat menurunkan berat kering akar dan komponen hasil tanaman padi. Ekstrak tusuk konde dilaporkan mampu menghambat pertumbuhan dan aktifitas akar sehingga proses fotosintesis terhambat akibatnya pertumbuhan tanaman tidak normal ( Nie et al., 2006). Secara fisiologis alelopat tusuk konde diketahui mampu menghambat 
aktifitas nitrat reduktase, glutamin sintetase, peroksidase dan alpa amilase yang berperan dalam proses metabolisme sel, serta menghambat proses respirasi sel (Nie, 2007).

Disisi lain bahwa ekstrak babandotan dapat menurunkan panjang radikula, koleoptil dan berat kering gandum (Triticum aesativum) (Singh et al., 2003), maupun pertumbuhan kecambah dan berat kering padi (Singh et al., 2004). Ekstrak pucuk babandotan dapat menghambat perkecambahan serta pertumbuhan akar dan batang boroko (Amaranthus caudatus), genjoran (Digitaria sanguinalis) dan selada (Lactuca sativa) (Noguchi, 2001). Biomassa babandotan yang berasal dari daun dan akar dilaporkan mampu menghambat pertumbuhan kacang panjang (Vigna sinensis). Selain itu panjang akar, tinggi dan biomassa tanaman lebih rendah pada tanah yang diberi campuran biomassa akar dan daun babandotan dibandingkan dengan kontrol (Batish et al., 2006). Potensi alelopati daun babandotan lebih besar dibandingkan bagian batang maupun akar (Xuan et al., 2004).

Alelopat kirinyuh yang berasal dari daun pada konsentrasi $5 \mathrm{~kg} / 20 \mathrm{~L}$ pelarut dapat menghambat perkembangan biji gulma maupun tanaman pangan seperti jagung, kedelai maupun kacang-kacangan (Adetayo et al., 2005). Alelopati dari kirinyuh juga dapat digunakan untuk mengendalikan gulma, salah satu spesies gulma yang dikendalikan adalah jajagoan (Echinochloa crus-galli) yang tumbuh pada pertanaman padi (Chung et al., 2001) dalam Adetayo et al. (2005). Disamping untuk mengendalikan gulma, alelopati kirinyuh juga dapat menekan serangan hama maupun penyakit pada tanaman kedelai (Ambika dan Poornima, 2004).

Sumber alelopati lainnya berasal dari gulma sembung rambat. Ekstrak daun sembung rambat dapat menghambat pertumbuhan kecambah gulma, tanaman sayuran maupun tanaman berkayu (Shao et al., 2005). Sembung rambat diketahui mampu melepaskan alelopat yang dapat menghambat perkecambahan pertumbuhan tanaman 
(Smith, 2005). Selain itu dilaporkan bahwa biomassa sembung rambat mampu menghambat perkecambahan dan pertumbuhan gulma Asystasia intrusa dan rumput jarum (Chrysopogon aciculatus). Biomassa yang berupa daun sembung rambat dapat menurunkan panjang akar dan berat segar kecambah (Ismail dan Mah, 2004).

Penelitian tentang potensi alelopati pada gulma tusuk konde, babandotan, kirinyuh dan sembung rambat pada tanaman sawi belum banyak dilakukan, oleh karena itu perlu dilakukan penelitian untuk menguji pengaruh alelopat dari gulma tersebut pada konsentrasi yang berbeda terhadap pertumbuhan dan hasil sawi. Tujuan dari penelitian ini adalah untuk menentukan alelopat yang paling menghambat perkecambahan sawi serta menjelaskan pengaruh konsentrasi alelopat berbagai jenis gulma terhadap perkecambahan sawi.

\section{METODE PENELITIAN}

Penelitian telah dilaksanakan pada bulan November 2008 sampai Januari 2009. Penelitian menggunakan Rancangan Acak Lengkap ( RAL ) yang terdiri dari dua faktor dan diulang tiga kali. Faktor pertama, jenis gulma, terdiri dari $\mathrm{G}_{1=}$ Tusuk konde (Wedelia trilobata), $\mathrm{G}_{2}=$ Babandotan (Ageratum conyzoides), $\mathrm{G}_{3}=$ Kirinyuh (Chromolaena odorata) dan $\mathrm{G}_{4}=$ Sembung rambat (Mikania micrantha). Faktor kedua adalah konsentrasi alelopat yang terdiri dari $\mathrm{K}_{1}(10 \mathrm{~g} / \mathrm{L}) ; \mathrm{K}_{2}(20 \mathrm{~g} / \mathrm{L}) ; \mathrm{K}_{3}(30 \mathrm{~g} / \mathrm{L}) ; \mathrm{K}_{4}(40 \mathrm{~g} / \mathrm{L})$ dan $\mathrm{K}_{5}(50$ g/L). Sebagai kontrol digunakan air.

\section{Persiapan Alelopat}

Tusuk konde, babandotan, kirinyuh dan sembung rambat yang digunakan sebagai sumber alelopat berasal dari hijauan yang masih segar yang diambil dari lahan di sekitar Fakultas Pertanian, Universitas Bengkulu. Hijauan selanjutnya dipotong-potong dengan ukuran kurang lebih $2 \mathrm{~cm}$ dan ditimbang sesuai dengan kebutuhan tiap-tiap perlakuan yaitu 10 g, 20 g, 30 g, 40 g dan 50 g. Hijauan tersebut kemudian direndam masing-masing 
dalam $1 \mathrm{~L}$ aquades selama 36 jam untuk selanjutnya disaring untuk memisahkan bagian padat dengan bagian cair dan disaring sekali lagi dengan menggunakan 2 lapis kertas saring Whatman No. 1 agar larutan benar-benar bersih (Nie, 2007).

\section{Pelaksanaan Penelitian}

Uji respon perkecambahan dilakukan dengan menggunakan petridish. Dua lapis kertas saring Whatman No. 1 ditempatkan pada petridish yang berdiameter $10 \mathrm{~cm}$ kemudian benih sawi disusun di atas kertas tersebut sebanyak 100 biji pada masingmasing petridish lalu ditambahkan $10 \mathrm{ml}$ alelopat sesuai perlakuan. Untuk kontrol hanya ditambahkan air dengan volume yang sama. Petridish kemudian diletakkan di ruang perkecambahan pada suhu ruang. Untuk menjaga kelembaban media perkecambahan, pemberian ekstrak dilakukan setiap 2 hari sekali dengan volume yang sama sampai kecambah berumur 1 minggu. Hal yang sama juga dilakukan pada kontrol. Variabel yang diamati meliputi persentase perkecambahan, panjang kecambah bagian atas, panjang akar kecambah, bobot segar kecambah, bobot segar akar kecambah serta bobot kering kecambah

\section{HASIL DAN PEMBAHASAN}

Hasil pengamatan secara visual pada penelitian di laboratorium menunjukkan bahwa ekstrak alelopat babandotan dan kirinyuh menghambat saat munculnya radikula. Namun demikian, kedua gulma tersebut tidak menekan persentase perkecambahan. Hambatan juga ditunjukkan oleh perbedaan warna kotiledon biji sawi. Pada perlakuan ekstrak gulma tusuk konde dan sembung rambat kotiledon berwarna hijau, sedangkan pada perlakuan ekstrak babandotan dan kirinyuh kotiledon berwarna kuning.

Hasil analisis keragaman pengaruh jenis gulma, konsentrasi dan interaksi terhadap variabel pengamatan disajikan pada Tabel 1. 
Tabel 1. Analisis Varian pada Berbagai Variabel yang Diamati pada Perkecambahan Sawi.

\begin{tabular}{llccc}
\hline \multirow{2}{*}{ No } & \multicolumn{2}{c}{ Variabel yang diamati } & \multicolumn{3}{c}{ F-hitung } \\
\cline { 3 - 5 } & & $\begin{array}{c}\text { Jenis } \\
\text { Gulma }\end{array}$ & Konsentrasi & Interaksi \\
\hline 1 & Persentase Perkecambahan & $2,61^{\mathrm{ns}}$ & $2,15^{\mathrm{ns}}$ & $0,26^{\mathrm{ns}}$ \\
2 & Panjang Kecambah Bagian Atas & $4,54^{* *}$ & $11,36^{* *}$ & $5,29^{* *}$ \\
3 & Panjang Akar Kecambah & $18,70^{* *}$ & $34,19^{* *}$ & $10,58^{* *}$ \\
4 & Bobot Segar Kecambah Bagian Atas & $62,02^{* *}$ & $21,79^{* *}$ & $8,60^{* *}$ \\
5 & Bobot Segar Akar Kecambah & $31,25^{* *}$ & $14,17^{* *}$ & $5,35^{* *}$ \\
6 & Bobot Kering Kecambah Bagian Atas & $20,09^{* *}$ & $39,74^{* *}$ & $6,37^{* *}$ \\
7 & Bobot Kering Akar Kecambah & $17,61^{* *}$ & $13,39^{* *}$ & $1,88^{\mathrm{ns}}$ \\
\hline
\end{tabular}

Keterangan : ** : berbeda sangat nyata

ns : berbeda tidak nyata

\section{Interaksi Konsentrasi Alelopat dan Jenis Gulma}

Hasil uji lanjut Polynomial Orthogonal terhadap interaksi antara jenis gulma dan konsentrasi alelopat disajikan pada Gambar 1, 2, 3, 4 dan 5.

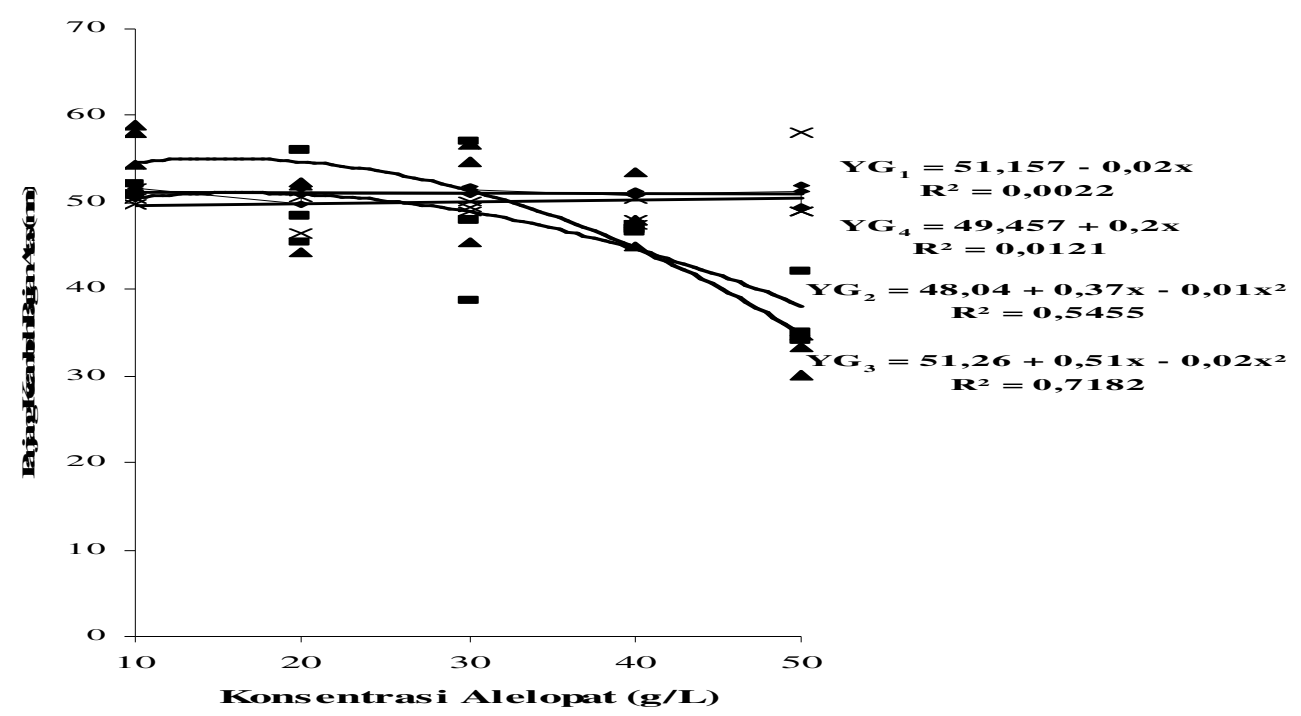

Gambar 1. Interaksi antara Konsentrasi Alelopat dan Jenis Gulma terhadap Panjang Kecambah Bagian Atas.

Peningkatan konsentrasi alelopat tusuk konde dari $10 \mathrm{~g} / \mathrm{L}$ hingga $50 \mathrm{~g} / \mathrm{L}$ dapat menekan panjang kecambah $\left(\mathrm{YG}_{1}=51,157-0,02 \mathrm{x}\right)$. Dengan demikian setiap peningkatan konsentrasi alelopat $10 \mathrm{~g} / \mathrm{L}$ panjang kecambah berkurang 0,02 $\mathrm{mm}$. Fenomena yang sama juga terjadi pada gulma babandotan dan kirinyuh. Hal ini diduga, alelopat telah mulai aktif 
pada konsentrasi tersebut sehingga menghambat pertumbuhan kecambah. Kecambah terpendek $(26,76 \mathrm{~mm})$ dihasilkan dari perlakuan ekstrak alelopat kirinyuh pada konsentrasi $50 \mathrm{~g} / \mathrm{L}$.

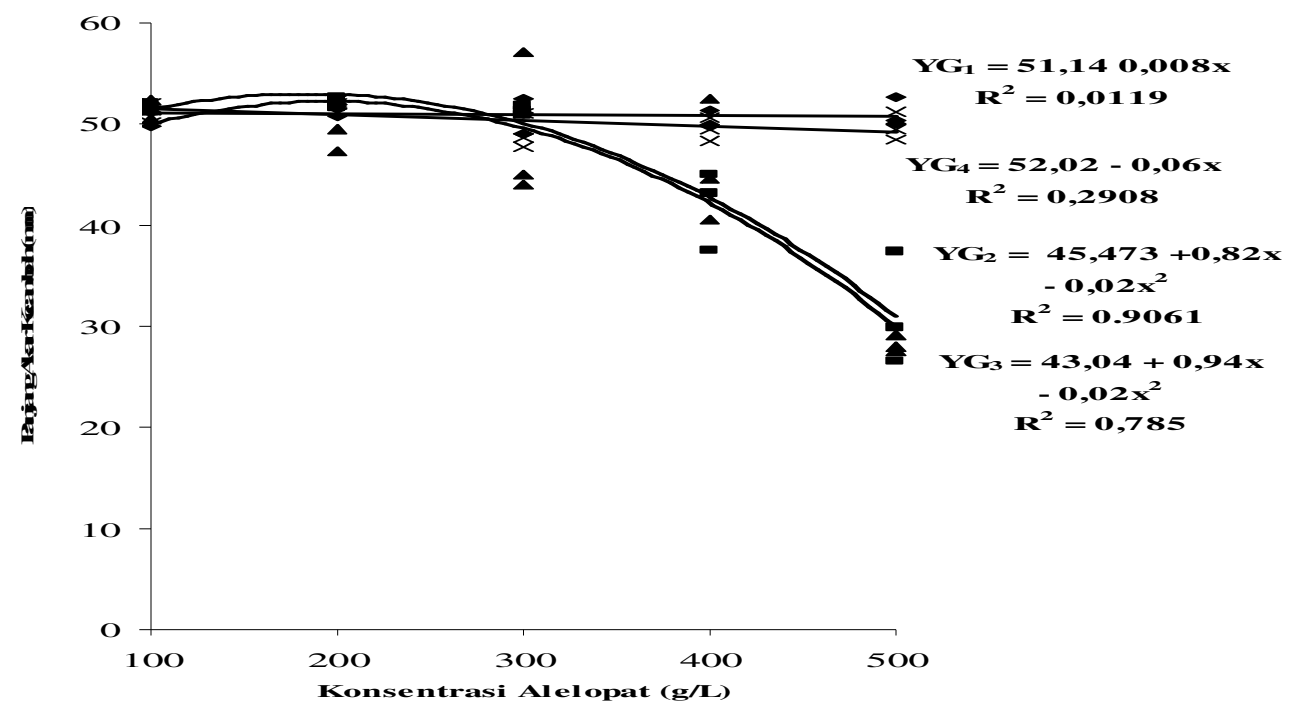

Gambar 2. Interaksi antara Konsentrasi Alelopat dan jenis Gulma terhadap Panjang Akar Kecambah.

Interaksi antara konsentrasi alelopat dan jenis gulma menghasilkan respon yang berbeda terhadap panjang akar kecambah. Konsentrasi ekstrak $10 \mathrm{~g} / \mathrm{L}$ hingga $50 \mathrm{~g} / \mathrm{L}$ dari gulma tusuk konde dan sembung rambat menekan panjang akar kecambah $\left(\mathrm{YG}_{1}=51,14-\right.$ 0,008x dan $\left.\mathrm{YG}_{4}=52,02-0,06 \mathrm{x}\right)$. Disisi lain, peningkatan konsentrasi dari $10 \mathrm{~g} / \mathrm{L}$ hingga 20,5 g/L ekstrak babandotan dan $10 \mathrm{~g} / \mathrm{L}$ hingga $23,5 \mathrm{~g} / \mathrm{L}$ untuk kirinyuh justru memacu pertumbuhan akar kecambah. Hal ini diduga pada konsentrasi tersebut ketersediaan zat alelopat masih relatif rendah sehingga belum cukup untuk menimbulkan pengaruh penghambatan yang berarti terhadap akar kecambah. Dengan meningkatnya konsentrasi alelopat dari 20,5 g/L hingga $50 \mathrm{~g} / \mathrm{L}$ untuk babandotan dan 23,5 g/L hingga $50 \mathrm{~g} / \mathrm{L}$ untuk kirinyuh, alelopat mampu menghambat pertumbuhan akar kecambah. Hal ini menunjukkan bahwa respon penghambatan zat alelopat mulai aktif pada konsentrasi 
tersebut sehingga menyebabkan penurunan panjang akar kecambah. Alelopat babandotan pada konsentrasi $50 \mathrm{~g} / \mathrm{L}$ paling menekan pertumbuhan akar kecambah sawi.

Jika dibandingkan dengan kontrol, hambatan pertumbuhan yang diakibatkan oleh alelopat terhadap akar kecambah berbeda-beda. Ekstrak tusuk konde, babandotan, kirinyuh dan sembung rambat masing-masing menekan akar kecambah sebesar 0,91\%, $39,38,45,15 \%$ dan $3,43 \%$. Alelopat kirinyuh terlihat paling menekan pertumbuhan akar kecambah dibandingkan dengan ketiga gulma lainnya.

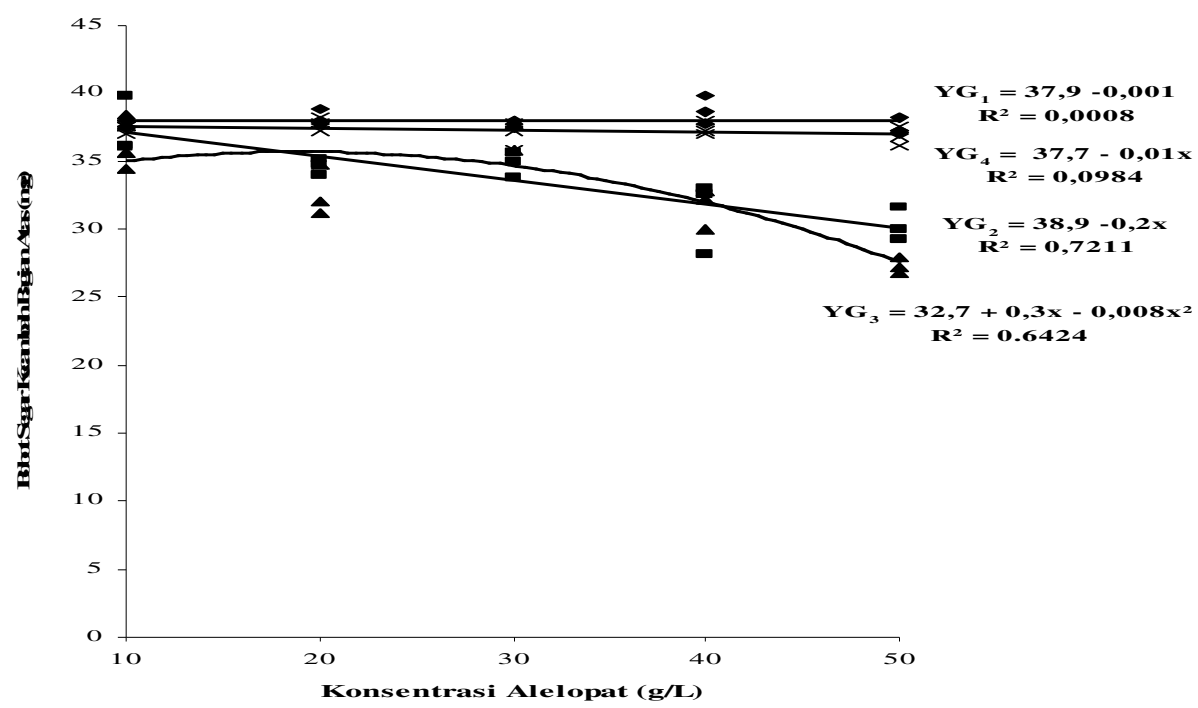

Gambar 3. Interaksi antara Konsentrasi Alelopat dan Jenis Gulma Terhadap Bobot Segar Kecambah Bagian Atas.

Konsentrasi alelopat tusuk konde dari $10 \mathrm{~g} / \mathrm{L}$ hingga $50 \mathrm{~g} / \mathrm{L}$ dapat meningkatkan bobot segar kecambah $\left(\mathrm{YG}_{1}=37,9+0,001 \mathrm{x}\right)$. Sebaliknya pada konsentrasi yang sama, ekstrak babandotan dan sembung rambat dapat menurunkan bobot segar kecambah $\left(\mathrm{YG}_{2}=\right.$ $39,0-0,2 \mathrm{x}$ dan $\left.\mathrm{YG}_{4}=37,7-0,01 \mathrm{x}\right)$. Disisi lain, ekstrak kirinyuh pada konsentrasi rendah dapat meningkatkan bobot segar kecambah tetapi pada konsentrasi diatas 18,75 g/L mulai menekan bobot segar kecambah. Hal ini diduga pada konsentrasi $10 \mathrm{~g} / \mathrm{L}$ hingga 18,75 g/L zat alelopat belum aktif berfungsi sebagai zat penghambat pertumbuhan. Sedangkan pada konsentrasi diatas 18,75 g/L alelopat mulai efektif berfungsi sebagai zat penghambat yang ditunjukkan dengan adanya penurunan terhadap bobot segar kecambah. 


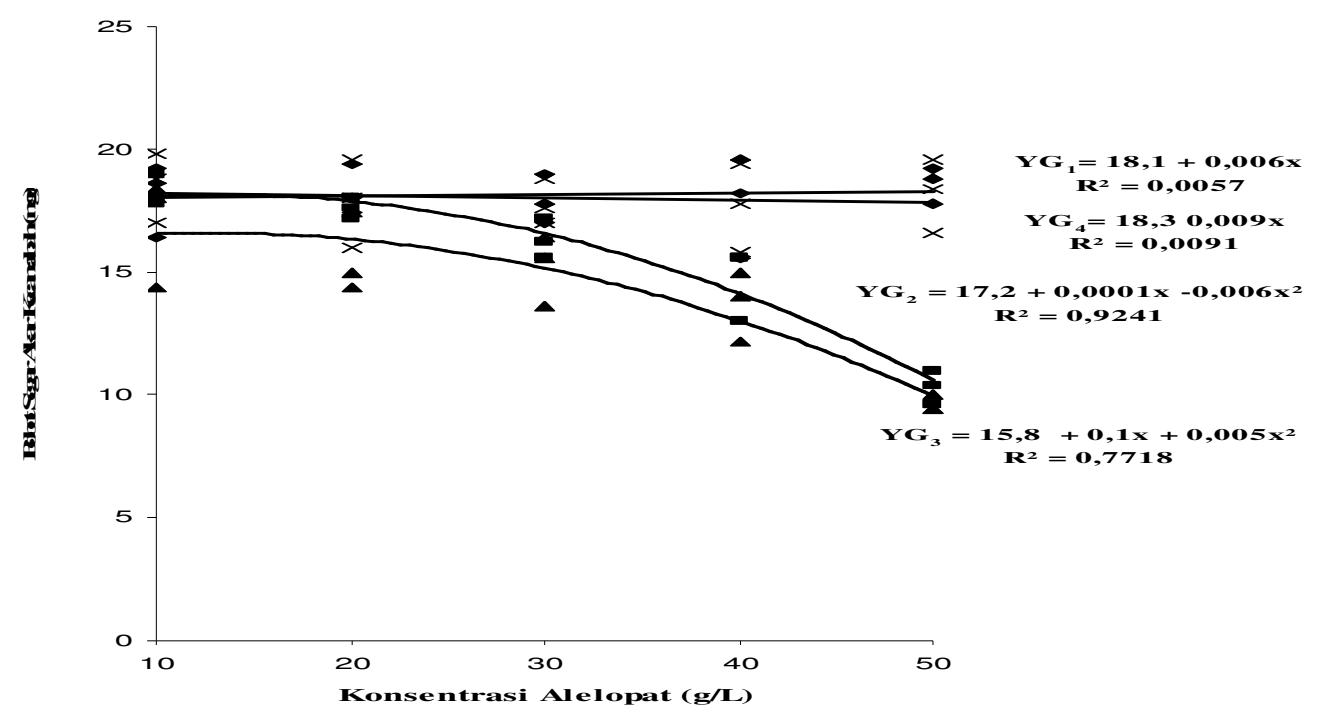

Gambar 4. Interaksi antara Konsentrasi Alelopat dan Jenis Gulma terhadap Bobot segar Akar Kecambah.

Konsentrasi alelopat tusuk konde hingga $50 \mathrm{~g} / \mathrm{L}$ dapat meningkatkan bobot segar akar kecambah $\left(\mathrm{YG}_{1}=18,1+0,006 \mathrm{x}\right)$. Sebaliknya pada konsentrasi yang sama ekstrak alelopat sembung rambat menurunkan bobot segar akar $\left(\mathrm{YG}_{4}=18,3-0,009 \mathrm{x}\right)$. Hambatan pertumbuhan akar kecambah juga ditunjukkan dari perlakuan ekstrak gulma babandotan dan kirinyuh. Dari keempat persamaan regresi di atas terlihat, bobot segar akar kecambah terendah dihasilkan dari alelopat babandotan pada konsentrasi $50 \mathrm{~g} / \mathrm{L}$ yaitu sebesar 7,2 mg.

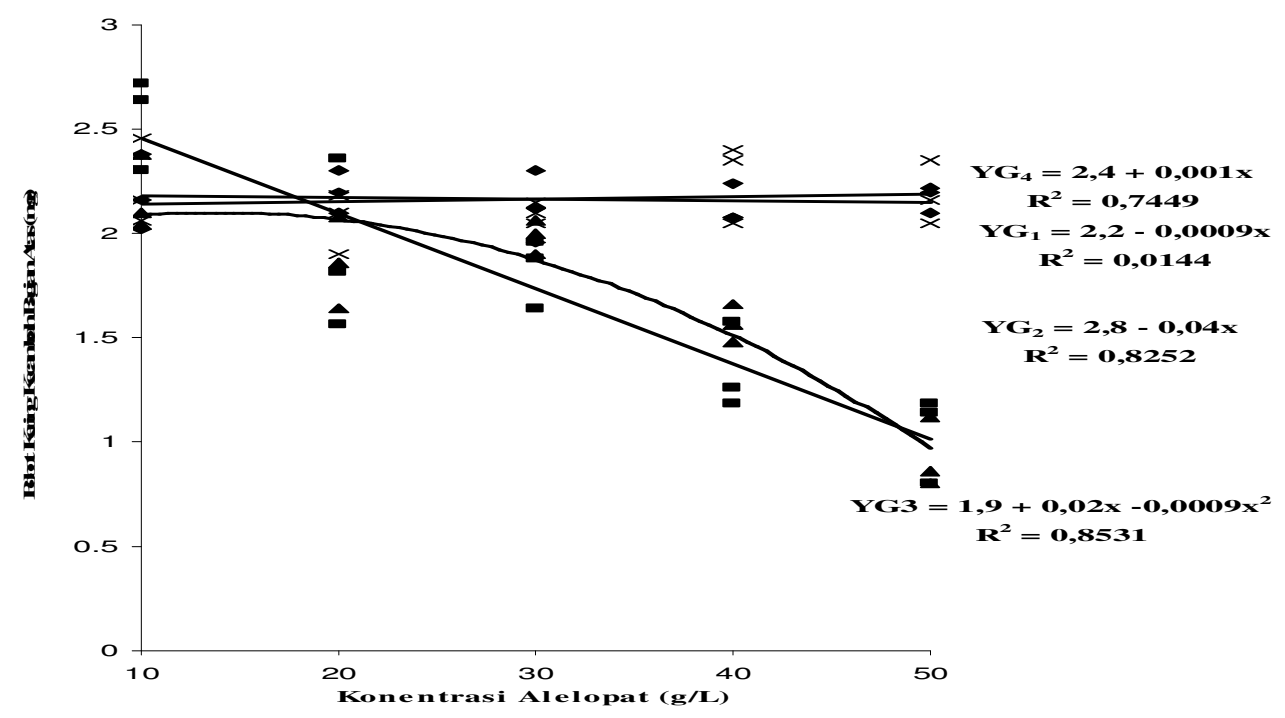


Gambar 5. Interaksi antara Konsentrasi Alelopat dan Jenis Gulma terhadap Bobot Kering Kecambah Bagian Atas.

Konsentrasi alelopat gulma tusuk konde, babandotan dan sembung rambat sampai dengan $50 \mathrm{~g} / \mathrm{L}$ mampu menekan bobot kering kecambah secara linear. Disisi lain, ekstrak kirinyuh menghasilkan respon kuadratik. Pada awalnya respon penghambatan terhadap bobot kering kecambah belum begitu terlihat. Namun pada konsentrasi 11,11 g/L hingga $50 \mathrm{~g} / \mathrm{L}$ terjadi penekanan terhadap bobot kering kecambah. Hal ini diduga pada konsentrasi $10 \mathrm{~g} / \mathrm{L}$ hingga 11,11 g/L belum merupakan konsentrasi yang efektif dalam menghambat pertumbuhan kecambah dan konsentrasi diatas $11,11 \mathrm{~g} / \mathrm{L}$ alelopat mulai aktif menghambat pertumbuhan yang ditandai dengan penurunan bobot kering kecambah.

Hasil penelitian ini secara umum menunjukkan, alelopat yang berasal dari gulma babandotan dan kirinyuh lebih menekan perkecambahan sawi dibandingkan dengan alelopat gulma tusuk konde dan sembung rambat. Penghambatan terhadap perkecambahan tersebut diduga karena adanya senyawa fitokimia yang bersifat alelopat yang terkandung dalam ekstrak babandotan dan kirinyuh memberikan respon penghambatan yang lebih besar dibandingkan dengan gulma tusuk konde dan sembung rambat. Xuan et al. (2004), melaporkan bahwa gulma babandotan menghasilkan beberapa zat alelopat antara lain asam galik, asam koumarin, asam protokatekuin, katekin, asam p-hidroksibenzoat, asam pkoumarin, asam benzoat dan asam sinapin. Senyawa-senyawa ini diketahui mampu menghambat pertumbuhan gulma Echibochloa crus-galli dan Monochoria vaginalis dengan persentase penekanan sebesar $70 \%$. Hal yang serupa juga dilaporkan bahwa gulma kirinyuh mampu memproduksi beberapa senyawa alelopat dari jaringan tubuhnya berupa senyawa alkaloid, saponin, tanin, asam koumarin, anthrakuinon, terpenoid, flavonoid, flobatanin, p-hidroksibenzoat dan kardiak glukosida dan senyawa ini juga berpotensi sebagi zat penghambat pertumbuhan tanaman (Afolabi et al, 2007). 
Selain itu dari hasil penelitian ini juga terlihat bahwa secara umum dengan meningkatnya konsentrasi alelopat yang diberikan diikuti dengan meningkatnya efikasi alelopat tersebut. Hal ini terlihat pada penekanan yang terjadi hampir pada semua variabel yang diamati kecuali persentase perkecambahan. Meningkatnya konsentrasi alelopat diikuti dengan meningkatnya yang zat-zat alelopat yang terkandung sehingga memperbesar daya hambatnya terhadap perkecambahan sawi. Hal yang sama dikemukakan oleh Pabinru (1979) bahwa faktor yang mempengaruhi besarnya daya hambat senyawa alelopat adalah konsentrasi zat penghambat, macam tanaman yang mengalami penghambatan dan lamanya penghambat bersama dengan tanaman yang dihambat. Shafer dan Gorisson (1986) melaporkan ada hubungan antara aktifitas alelopat dan konsentrasinya. Makin besar konsentrasi alelopat dalam residu maka makin besar daya hambatnya dalam mempengaruhi pertumbuhan tanaman dan hal ini spesifik untuk suatu tanaman

Dengan semakin meningkatnya konsentrasi, tanaman menunjukkan kecenderungan semakin teracuni. Proses hambatan terjadi pada setiap fase dalam proses perkecambahan mulai dari penyerapan air, pengaktifan enzim, respirasi maupun perkecambahan. Dalam penyerapan air Moenandir (1990) mengemukakan bahwa pembusukan organ tanaman yang berpotensi alelopati akan menghasilkan senyawa organik dan aromatik seperti asam vinilat, siringat, kafeat, ferulat dan P-hidroksi benzoat. Senyawa-senyawa ini diketahui dapat meningkatkan konsentrasi larutan di sekitar benih sehingga menurunkan tekanan difusi air, sehingga benih terhambat menyerap air, akibatnya gagal atau mengalami hambatan untuk berkecambah. Dijelaskan juga bahwa asam kafeat dapat menghambat enzim $\alpha$ dan $\beta$-amilase yang aktif pada fase pencernaan dalam proses perkecambahan. Sastroutomo (1990) juga mengemukakan bahwa sintesa biji dan kecambah dihambat oleh asam ferulat dan koumarin. Selanjutnya dikemukakan bahwa hormon tumbuh Giberelin 
(GA) dan Asam Indol Asetat (IAA) yang aktif dalam proses perkecambahan, aktifasinya dihambat oleh senyawa 3-4 -dihidroksi benzoat dan asam ferulat, sehingga proses pembentukan sel pada titik tumbuh mengalami penghambatan.

Respon penghambatan yang terjadi pada panjang kecambah dan panjang akar kecambah menunjukkan adanya aktifitas alelopati yang menghambat perpanjangan dan perbanyakan sel. Rice (1974) mengemukakan adanya senyawa alelopat dapat menghambat perpanjangan dan perbanyakan sel. Dari hasil penelitian ini terlihat bahwa panjang kecambah dan panjang akar kecambah tanaman sawi pada perlakuan kontrol lebih panjang dibandingkan dengan yang diperlakukan dengan alelopat. Hambatan yang terjadi pada proses perkecambahan dan pertumbuhan kecambah selanjutnya berpengaruh pada bobot basah dan bobot kering kecambah. Hambatan tersebut disebabkan karena terganggunya proses metabolisme di dalam biji sawi pada setiap tahapan proses perkecambahan.

\section{Pengaruh Konsentrasi Alelopat}

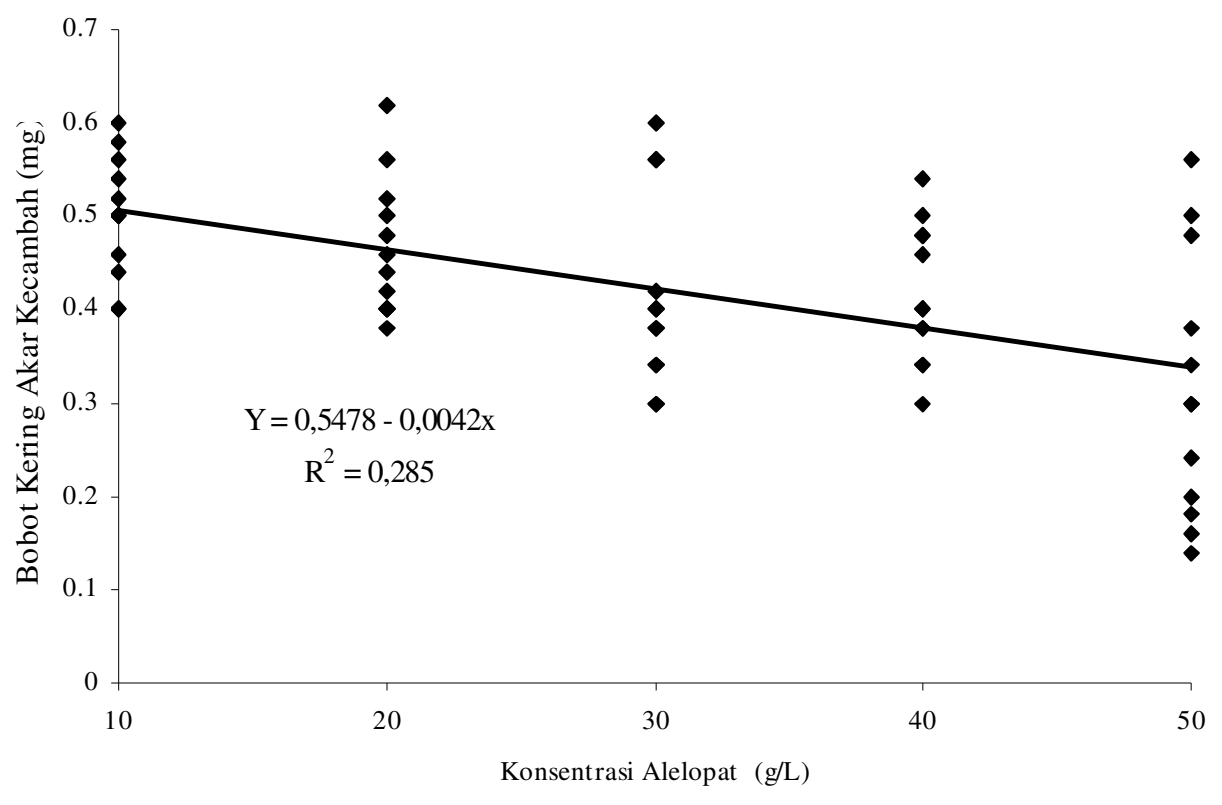

Gambar 6. Pengaruh Konsentrasi Alelopat terhadap Bobot Kering Akar Kecambah Sawi. 
Terdapat hubungan linear negatif antara konsentrasi alelopat dan bobot kering akar kecambah $(\mathrm{Y}=0,5478-0,0042 \mathrm{x})($ Gambar 6). Bobot kering akar kecambah tertinggi diperoleh pada konsentrasi $10 \mathrm{~g} / \mathrm{L}(0,506 \mathrm{mg})$, sedangkan bobot kering terendah diperoleh pada konsentrasi $50 \mathrm{~g} / \mathrm{L}(0,338 \mathrm{mg})$. Hal ini diduga, dengan meningkatnya konsentrasi alelopat maka terjadi peningkatan ketersediaan zat-zat alelopat sehingga memperbesar respon penghambatannya terhadap bobot kering akar kecambah. Menurut Pabinru (1979), besarnya daya hambat senyawa alelopat dipengaruhi oleh konsentrasi penghambat, jenis tanaman dan lamanya penghambat bersama dengan tanaman. Hal yang sama juga dikemukakan oleh Steinsiek et al. (1982), dan Shettel dan Balke (1983) dalam Setyowati dan Suprijono (2001) bahwa daya hambat alelopat terhadap pertumbuhan dan perkembangan tanaman dipengaruhi oleh konsentrasi ekstrak, sumber ekstrak, temperatur ruangan, jenis tumbuhan yang dievaluasi dan saat aplikasi.

\section{KESIMPULAN DAN SARAN}

Alelopat kirinyuh (Chromolaena odorata) lebih menekan perkecambahan sawi dibandingkan alelopat tusuk konde, babandotan atau sembung rambat. Alelopat kirinyuh menekan panjang kecambah bagian atas, panjang akar kecambah, bobot segar kecambah, bobot segar akar kecambah dan bobot kering kecambah bagian atas masing - masing sebesar $42,63 \%, 45,15 \%, 28,23 \%, 56,16 \%$ dan $56,27 \%$. Konsentrasi $50 \mathrm{~g} / \mathrm{L}$, baik untuk alelopat gulma babandotan maupun kirinyuh, paling menekan pertumbuhan kecambah biji sawi.

Perlu dilakukan penelitian yang serupa pada tanaman yang sama dengan menggunakan metode ekstraksi, pelarut, waktu dan cara aplikasi yang berbeda untuk mendapatkan perbandingan hasil. 


\section{DAFTAR PUSTAKA}

Adetayo. O. B., O. I. Lawal, B. S. Alabi and O. F. Owolade. 2005. Allelopathic effect of siam weed (Chromolaena odorata) on seed germination and seedling performance of selected crop and weed species. The Fourth Congress on Allelopathy, August 2005.

Afolabi, C. A., E. O. Ibukun and I. A. Dan-ologe. 2007. Phytochemical constituents and antioxidant properties of extracts from the leaves of Chromolaena odorata. Scientific Research and Essay 2(6)191-194. www.academicjournals.org. Dowmload 5 April 2009.

Ambika, S. R and S. R., Poornima, S. 2004. Allelochemicals from Chromolaena odorata (L.) King and Robinson for increasing crop productivity. ACIAR (55): 19-24.

Batish, D. R., H. P. Singh., S. Kaur and R. K. Kohli. 2006. Phytotoxicity of Ageratum conyzoides residues towards growth and nodulation of Cicer arietinium. Agriculture, Ecosystem and Environment 113(1-4):399-401.

Fitriana, M., Susilawati dan F. Wardani. 2005. Pemanfaatan Ekstrak Umbi Teki (Cyperus rotundus L.) dan Alang-alang (Imperata cylindrica L.) Terhadap Pertumbuhan Gulma dan Hasil Mentimun (Cucumis sativus L.). Prosiding Konferensi Nasional Ke-17 Himpunan Ilmu Gulma Indonesia, Yogyakarta. 20-21 Juli 2005.

Ismail. B. S and L. S. Mah.. 2004. Effects of Mikania Micrantha H. B. K on germination and growth of weed species. Plant and Soil 157(1):107-113.

Nie, C. 2007. Allelopathic potential of Wedelia trilobata L. on rice. Acta Agronomica Sinica 30 (9) : 942-946.

Nie, C., Z. Rensen., L. H. Shou and L. Mei. 2006. Allelopathic potentials of Wedelia trilobata on Brassica parachinensis and its physiological mechanism of action. http://www.regional.org. Download 25 April 2009.

Noguchi H. K. 2001. Assessment of the allelopathic potential of Ageratum conyzoides. Biological Plantarum 44(2):309-311.

Pabinru, A. M. 1979. Penelitian alelopati pada beberapa tanaman di tanah kering. Thesis Pasca Srjana Institut Pertanian Bogor, Bogor. (Tidak dipublikasikan).

Rice, E. L. 1974. Allelopathy. Academic Press New York, San Fransisco-London.

Sastroutomo, S. S. 1990. Ekologi Gulma. PT. Gramedia, Jakarta.

Setyowati, N dan E. Suprijono. 2001. Efikasi alelopati teki formulasi cairan terhadap gulma Mimosa invisa dan Melochia chorchorifolia. JIPI 3(10):16-24.

Setyowati, N., M. Simarmata dan S. Yanuarti. 1999. Respon perkecambahan beberapa tanaman pangan dan hortikultura terhadap alelopati teki (Cyperus rotundus L.). Agrotropika IV(1):37-41. 
Shafer, W. E and Gorrison. 1986. Allelopathic effects of soil incorporated asparagus roots on lettucce, tomato and asparagus seedling emergence. Hoticultura Science 21(1):8284.

Shao. H., S. Peng., X. Wei., D. Zhang and C. Zhang. 2005. Potential allelochemicals an invasive weed Mikania micrantha H.B.K. Chemical Ecology 31(7):1657-1668.

Shiming, L. 2007. Allelopathy in South China Agroecosystem. http://www.regional.au.org. Download 12 November 2007.

Singh, H. P., D. R. Batish., R. Kaur and R. K. Kohli. 2003. Phytotoxic interference of Ageratuim conyzoides with wheat (Triticum aesativum). Agronomy and Crop Science 189(5):341-346.

Singh, H. P., D. R. Batish., R. Kaur and R. K. Kohli. 2004. Phytotoxic interference of Ageratuim conyzoides with rice. Agronomy and Crop Science.

Smith. A. C. 2005. Flora Vitiensis nova. A new flora of Fiji Volume 5. National Tropical Botanical Garden.

Sukman, Y dan Yakup. 2002. Gulma dan Tehnik Pengendaliannya. Edisi Revisi. PT. raja Grafindo Persada, Jakarta.

Xuan, T. D., N. H. Hong., T. D. Khanh and C. M. Min. 2004. Assessment of phytotoxic action of Ageratum conyzoides L. (billy goat weed) on weeds. Crop Protection 23(10):915-922. 